\title{
EFFECT OF DIETARY SUPPLEMENTATION OF L-THREONINE ON GROWTH PERFORMANCE AND ECONOMICS IN BROILER CHICKENS
}

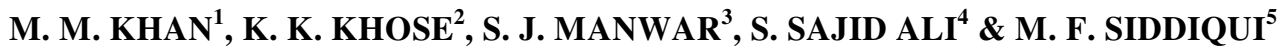 \\ ${ }^{I}$ Post-Graduate Scholar, Department of Poultry Science, Post Graduate Institute of Veterinary and Animal Sciences (PGIVAS), \\ Akola, Maharashtra Animal and Fishery University (MAFSU), Nagpur Maharashtra, India \\ ${ }^{2,3}$ Assistant Professor, Department of Poultry Science, PGIVAS, Akola, MAFSU, Nagpur, Maharashtra, India \\ ${ }^{4}$ Assistant Professor, Department of Animal Genetics and Breeding, PGIVAS, Akola, MAFSU, Nagpur, Maharashtra, India \\ ${ }^{5}$ Assistant Professor, Teaching Veterinary Clinical Complex PGIVAS, Akola, MAFSU, Nagpur, Maharashtra, India
}

\begin{abstract}
Three hundred straight-run Vencobb 400 day-old broiler chicks, were randomly distributed into five treatment groups, having three replicates containing 20 chicks in each and reared up to 6 weeks of age. The dietary treatment groups were the threonine deficient diet-Negative Control $(A)$, diet with threonine as per NRC Control (B), diet containing $L$ - threonine at $10 \%(C), 20 \%(D), 30 \%(E)$ above NRC (1994) recommendation. The treatment group C showed significantly higher $(P<0.05)$ cumulative weight gain than group A receiving threonine deficient diet. The threonine supplemented groups $C, D$ and $E$ showed numerically higher cumulative weight gain, but non-significant than group B receiving diet as per the NRC. The birds from treatment group C showed significantly higher cumulative feed consumption, than treatment group $A$. The cumulative feed consumption is numerically higher in treatment groups $C, D$ and $E$ than control group B. The cumulative feed conversion ratio (FCR) was non-significant in all treatment groups. The treatment group C and D supplemented with L-threonine at 10 and $20 \%$, respectively showed better FCR than other treatment groups. The overall mortality in broilers, during the experimental period was within normal range. The net profit per kg live weight was $R$ s 16.38, 16.46, 18.26, 16.73 and 16.21 for groups $A, B, C, D$ and $E$, respectively. The birds from group C receiving diet $10 \%$ L-threonine above NRC recorded highest net profit per $\mathrm{kg}$, followed by the birds from groups $D, B, A$ and $E$. Thus, it may be concluded that the dietary supplementation of L-threonine at 10\% above NRC (1994) was found to be beneficial, in terms of improved growth performance and economic returns in broiler chickens.
\end{abstract}

KEYWORDS: L-Threonine, Diet, Performance, Economics \& Broilers

Received: Oct 07, 2017; Accepted: Oct 27, 2017; Published: Nov 07, 2017; Paper Id.: IJASRDEC201723

\section{INTRODUCTION}

An important objective of the least cost formulation of broiler diets is to provide sufficient amounts of most limiting amino acids to support the needs of tissue maintenance and growth (11). Marginal dietary deficiencies of threonine may result in economic losses, from increased feed conversion and reduced breast meat accretion. It is therefore, important to meet the minimum level of threonine in a broiler diet. As threonine has its role in optimal growth, therefore, meeting the threonine requirement in least cost formulation with the supplementation of crystalline L-threonine may reduce dietary crude protein, which ultimately can reduce the feed cost (10). In poultry nutrition, the essential amino acids are of great concern and of which threonine is the third limiting amino acid after methionine and lysine in diets of broiler chickens (9). Adequate digestible Threonine levels are needed to support optimum growth (13) because it serves as important component of body protein and 
plays an important role as precursor of lysine and serine (17). Threonine improves the livability of heat stressed broilers (1). Increased dietary threonine concentration is known to improve nitrogen retention in broiler chicks; therefore changing level of threonine concentration is an important tool to improve nitrogen utilization (7). Several researchers have found that weight gain, feed conversion ratio (14), carcass characteristic (6) and immunity of broiler could be improved with an increase of threonine in the diet. Broilers fed low protein with threonine supplemented diets achieved the same high level of growth performance that was achieved by broilers fed high protein diets (12) while the amount of feed stuff and feed cost were both reduced. The threonine requirement of broiler chicken at various ages is variable and factors such as dietary crude protein breed, sex, age and main bird forming diet can affect the threonine requirements (4). Keeping above facts in view, the present investigation was planned to optimize the level of L-Threonine for broiler chickens.

\section{MATERIALS AND METHODS}

\section{Experimental Design and Management of Birds}

The experiment was carried out on 300 day-old Vencobb-400 straight run commercial broiler chicks for a period of 42 days (from $7^{\text {th }}$ May, 2016 to $17^{\text {th }}$ June, 2016) in the Department of Poultry Science, Post Graduate Institute of Veterinary and Animal Sciences, MAFSU, Akola. Three hundred straight run 'Cobb 400' day-old broiler chicks were randomly distributed into five treatment groups having three replicates containing 20 chicks in each and reared up to 6 weeks of age. The diets were formulated as per BIS, 2007(3), while threonine level was maintained as per NRC, 1994 (16). The dietary treatment groups were the threonine deficient diet-Negative Control (A), Control diet containing threonine level as per NRC (B), diet containing L- threonine 10\% (C), 20\% (D), 30\% (E) above NRC recommendation. All the diets were isocaloric and isonitrogeneous. The experimental design used for housing the broilers is presented in Table 1 .

Table 1: Experimental Design used for Housing of Broilers

\begin{tabular}{|l|l|c|c|c|}
\hline $\begin{array}{c}\text { Treatment } \\
\text { Group }\end{array}$ & \multicolumn{1}{|c|}{ Treatment Group Details } & $\begin{array}{c}\text { No. of } \\
\text { Birds/ } \\
\text { Replicate }\end{array}$ & $\begin{array}{c}\text { No. of } \\
\text { Replicates } \\
\text { /Treatment }\end{array}$ & $\begin{array}{c}\text { Total } \\
\text { Number } \\
\text { of Birds }\end{array}$ \\
\hline A & $\begin{array}{l}\text { Threonine deficient diet } \\
\text { (Negative Control) }\end{array}$ & 20 & 3 & 60 \\
\hline B & $\begin{array}{l}\text { Diet with threonine level as per } \\
\text { NRC (Control) }\end{array}$ & 20 & 3 & 60 \\
\hline C & $\begin{array}{l}\text { Diet with L-threonine level 10\% } \\
\text { above NRC }\end{array}$ & 20 & 3 & 60 \\
\hline D & $\begin{array}{l}\text { Diet with L-threonine level 20\% } \\
\text { above NRC }\end{array}$ & 20 & 3 & 60 \\
\hline E & $\begin{array}{l}\text { Diet with L-threonine level 30\% } \\
\text { above NRC }\end{array}$ & 20 & 3 & 60 \\
\hline \multicolumn{2}{|l}{ Total Number of Birds } & & $\mathbf{3 0 0}$ \\
\hline
\end{tabular}

The standard and uniform managemental practices were followed, for all treatment groups throughout the experimental period. The birds were offered ad-lib fresh and clean drinking water, throughout the experiment. The immunization against Ranikhet Disease (B1 strain) and Infectious Bursal Disease (IBD Intermediate strain) vaccination was carried out on $7^{\text {th }}$ and $14^{\text {th }}$ day, respectively, followed by booster doses on $21^{\text {st }}$ day and $28^{\text {th }}$ day through drinking water. 


\section{Procurement of Ingredients and Feed Formulation}

The good quality feed ingredients were procured from local market for preparation of experimental diets. The Lthreonine was supplied by M/s. Evonik India Pvt. Ltd. Andheri East, Mumbai, Maharashtra, India. The feeding of broilers was done in three phases as pre-starter (300 g/bird), starter (700 g/bird) and then finisher for all treatment groups. As per the plan of experiment, the composition of broiler feed for pre-starter, starter and finisher have been presented in Table 2.

Table 2: Ingredient (\%) and Nutrient Composition (\%) of Groups A (Negative Control Group) and B (Control Group)

\begin{tabular}{|c|c|c|c|c|c|c|}
\hline \multirow{2}{*}{ Ingredients (\%) } & \multicolumn{2}{|c|}{ Pre-starter } & \multicolumn{2}{|c|}{ Starter } & \multicolumn{2}{|c|}{ Finisher } \\
\hline & Group A & Group B & Group A & Group B & Group A & Group B \\
\hline Maize & 57.98 & 57.56 & 56.36 & 56.00 & 59.970 & 59.200 \\
\hline Soybean meal & 18.60 & 23.90 & 23.30 & 29.00 & 19.380 & 25.570 \\
\hline Maize gluten meal (60\%) & 7.00 & 6.00 & 3.50 & 3.00 & 3.000 & 2.000 \\
\hline Groundnut Meal & 7.00 & 3.00 & 5.50 & 1.00 & 5.000 & 1.000 \\
\hline Meat cum bone meal (MBM) & 5.00 & 5.00 & 4.50 & 4.00 & 4.500 & 3.700 \\
\hline Vegetable oil & 1.60 & 1.80 & 4.00 & 4.13 & 5.200 & 5.500 \\
\hline Dicalcium phosphate (DCP) & 0.70 & 0.70 & 0.75 & 0.85 & 0.850 & 1.000 \\
\hline Limestone powder (LSP) & 0.80 & 0.80 & 0.90 & 0.90 & 0.900 & 0.900 \\
\hline Salt & 0.25 & 0.25 & 0.25 & 0.25 & 0.250 & 0.250 \\
\hline Trace mineral premix* & 0.15 & 0.15 & 0.15 & 0.15 & 0.150 & 0.150 \\
\hline Vitamin premix & 0.10 & 0.10 & 0.10 & 0.10 & 0.100 & 0.100 \\
\hline DL-Methionine & 0.12 & 0.12 & 0.15 & 0.15 & 0.130 & 0.130 \\
\hline L-Lysine & 0.34 & 0.26 & 0.18 & 0.11 & 0.120 & 0.050 \\
\hline Choline chloride & 0.06 & 0.06 & 0.06 & 0.06 & 0.150 & 0.150 \\
\hline Toxin binder & 0.10 & 0.10 & 0.10 & 0.10 & 0.100 & 0.100 \\
\hline Coccidiostat & 0.05 & 0.05 & 0.05 & 0.05 & 0.050 & 0.050 \\
\hline Sodium bicarbonate & 0.15 & 0.15 & 0.15 & 0.15 & 0.150 & 0.150 \\
\hline TOTAL & 100.00 & 100.00 & 100.00 & 100.00 & 100.00 & 100.00 \\
\hline \multicolumn{7}{|c|}{ Nutrient Composition on Dry Matter Basis } \\
\hline $\begin{array}{l}\text { Metabolizable energy } \\
(\mathrm{kcal} / \mathrm{kg})\end{array}$ & 3007.14 & 3002.93 & 3102.34 & 3100.36 & 3204.70 & 3203.87 \\
\hline Crude protein $(\%)$ & 23.02 & 23.01 & 22.01 & 22.05 & 20.05 & 20.06 \\
\hline Ether extract $(\%)$ & 4.69 & 4.85 & 6.91 & 6.97 & 8.20 & 8.38 \\
\hline Calcium $(\%)$ & 1.01 & 1.03 & 1.02 & 1.02 & 1.03 & 1.01 \\
\hline Total phosphorus $(\%)$ & 0.73 & 0.73 & 0.70 & 0.70 & 0.70 & 0.69 \\
\hline Available phosphorus (\%) & 0.47 & 0.47 & 0.46 & 0.45 & 0.47 & 0.46 \\
\hline Crude fiber $(\%)$ & 4.03 & 3.92 & 3.99 & 3.87 & 3.77 & 3.70 \\
\hline Total lysine $(\%)$ & 1.30 & 1.30 & 1.20 & 1.20 & 1.03 & 1.04 \\
\hline Total methionine $(\%)$ & 0.50 & 0.50 & 0.50 & 0.50 & 0.45 & 0.45 \\
\hline Total Threonine (\%) & 0.76 & 0.80 & 0.76 & 0.80 & 0.69 & 0.72 \\
\hline
\end{tabular}

The diets $\mathrm{C}, \mathrm{D}$ and $\mathrm{E}$ were formulated, by adding L-threonine at 10, 20 and 30\% above NRC (1994) recommendation to control diet group B.

*Trace Mineral Mixture: - Each kg contains: Copper-15g, Iodine-2g, Iron-90g, Manganese-100g, Selenium-0.3g and Zinc-80g.

${ }^{\#}$ Vitamin Premix: -Each 500g contains: Vit. A12.50 MIU, Vit. D3-2.50 MIU, Vit. E-12g, Vit. K-1.50g, Thiamine (B1)-1.50g, Riboflavin (B2)-5g, Pyridoxine (B6)-2g, Cyanocobalamin (B12)- 0.015g, Niacin-15g, Cal D Pantothenate-10g and Folic acid-0.50g. 


\section{Data Collection}

Data was collected on weekly weight changes determined by weighing the birds on weekly basis and replicate wise weight gain was calculated by subtracting the weight of the previous week from that of the current week. The feed intake was determined by subtracting the left-over feed from the feed offered, while feed conversion ratio was calculated as average feed intake divided by average weight gain taking into consideration of mortality, if any. The cost of rearing the birds for experiment was calculated by considering the prevailing costs of chicks, feed, litter and vaccine etc.

\section{Statistical Analysis}

Data were subjected to statistical analysis (ANOVA) by using Complete Randomized Design (23). The treatment means were compared by critical differences (CD) and Analysis of Variance.

\section{RESULTS AND DISCUSSIONS}

\section{Body Weight Gain}

The treatment group $\mathrm{C}$ showed significantly higher $(\mathrm{P}<0.05)$ cumulative weight gain than group A receiving threonine deficient diet (Table 3). The threonine supplemented groups C, D and E showed numerically higher cumulative weight gain, than group B receiving diet as per the NRC recommendation, whereas the statistical difference was nonsignificant. However, the birds from group C recorded higher cumulative weight gain in, as compared to all treatment groups. These results are in accordance with earlier report stating that the relative body weights were increased at different total dietary threonine levels. However, he also reported that increase in threonine requirements for broilers, raised in builtup litter environments to microbial challenges, because threonine involved in mucin formation and mucin control microbial communities and nutrient availability in the gut (5). The supplementation of L-threonine in broiler diet improved growth performance and intestinal morphology, by increasing crypt depth, villi height and width of jejunum and ileum segment in broilers (19). Similarly, the use of methionine and threonine in broiler diets above NRC recommendations, considered as a better nutritional strategy, to overcome unfavourable stress conditions by improving immune cells in tropical area. They indicated that, threonine and methionine requirements of broilers, based on NRC recommendations are not sufficient to meet the requirements of new commercial broilers (15). The higher body weight gain in $0.75 \%$ L-threonine, supplemented to the broilers up to 0 to 42 days. They also observed that, L-threonine improved villus height in jejunum and ileum (22). The dietary inclusion of threonine had significant influence on body weight gain, in Japanese quail breeders (21).

\section{Feed Consumption}

The birds from treatment group C received diet containing 10\% L-threonine level, above NRC recommendation showed significantly $(\mathrm{P}<0.05)$ higher cumulative feed consumption, than treatment group A (Table 3). The cumulative feed consumption is numerically higher in treatment groups $\mathrm{C}, \mathrm{D}$ and $\mathrm{E}$, receiving diet L-threonine than control group B, whereas, there was non-significant difference in groups B, C, D and E. The results are in accordance with earlier reported increasing threonine supplementation improved feed intake, especially in high CP diets in 0-3 and 3-6 week of age (4). Similarly, the threonine requirements of high yield and classic broilers were similar and greater than for the leghorn strain (20). However, the highest feed consumption at 110 and 115 level of threonine (8), whereas the improved feed consumption on supplementation of threonine and reported that, NRC recommendation is adequate with no harmful effect $(7,2)$. 


\section{Feed Conversion Ratio (FCR)}

The statistical analysis of data revealed that there was non-significant difference in all treatment groups (Table3). The treatment group C and D supplemented with L-threonine at 10 and $20 \%$, respectively were numerically better than all treatment groups. The results are in the agreement with earlier researcher reported that, the supplementation of $0.80 \%$ threonine in female broilers showed better feed conversion ratio (1). However, supplementation of L-threonine in broilers showed better feed conversion ratio $(2,18)$.

\section{Mortality}

The overall mortality in broilers, during the experimental period was 5.00, 6.67, 3.33, 5.00 and $6.67 \%$ in treatment groups A, B, C, D and E, respectively, which occurred in all treatment groups, mainly due to heat stroke.The experiment was conducted from $7^{\text {th }}$ May to $17^{\text {th }}$ June, during summer period; the ambient temperature was ranged from i.e. $40-46^{0} \mathrm{C}$. The lower mortality was observed in birds fed $10 \%$ L-threonine, above NRC level. Similarly, the mortality did not vary with threonine supplementation, in male broiler diet (24).

Table 3: Growth Performance of Broilers Supplemented L-Threonine at different Levels

\begin{tabular}{|c|c|c|c|c|c|c|c|c|}
\hline \multirow{2}{*}{ Treatment Groups } & \multicolumn{6}{|c|}{ Age (Weeks) } & \multirow{2}{*}{ Pooled Mean } & \multirow{2}{*}{ CD } \\
\hline & I & II & II & IV & V & VI & & \\
\hline \multicolumn{9}{|c|}{ Body Weight Gain (g/Bird) } \\
\hline $\mathbf{A}$ & $86.58 \pm 2.25$ & $226.62 \pm 4.18$ & $459.76 \pm 5.59$ & $766.79 \pm 8.30$ & $1203.62 \pm 27.92$ & $1568.91 \pm 63.46$ & $718.71 \pm 128.30^{\mathrm{a}}$ & \multirow{5}{*}{$43.430^{*}$} \\
\hline B & $91.27 \pm 2.60$ & $255.85 \pm 6.56$ & $499.93 \pm 10.27$ & $811.99 \pm 31.16$ & $1223.39 \pm 55.78$ & $1589.65 \pm 77.72$ & $745.35 \pm 128.87^{\text {ab }}$ & \\
\hline $\mathbf{C}$ & $83.88 \pm 1.93$ & $252.07 \pm 2.93$ & $499.45 \pm 9.96$ & $846.98 \pm 16.91$ & $1318.00 \pm 9.91$ & $1704.19 \pm 13.55$ & $784.10 \pm 139.72^{b}$ & \\
\hline D & $94.77 \pm 3.54$ & $257.27 \pm 6.29$ & $496.30 \pm 8.53$ & $817.55 \pm 33.69$ & $1214.23 \pm 63.92$ & $1618.52 \pm 98.00$ & $749.77 \pm 130.64^{\mathrm{ab}}$ & \\
\hline $\mathbf{E}$ & $92.92 \pm 2.35$ & $261.88 \pm 7.26$ & $495.58 \pm 9.66$ & $834.01 \pm 36.95$ & $1261.42 \pm 54.19$ & $1624.76 \pm 82.41$ & $761.76 \pm 132.48^{\mathrm{ab}}$ & \\
\hline \multicolumn{8}{|c|}{ Feed Consumption (g/Bird) } & \multirow{6}{*}{$60.955^{*}$} \\
\hline $\mathbf{A}$ & $109.28 \pm 2.14$ & $313.23 \pm 2.03$ & $652.19 \pm 9.08$ & $1106.51 \pm 13.96$ & $1819.75 \pm 47.81$ & $2562.95 \pm 91.36$ & $1093.99 \pm 209.60^{\mathrm{a}}$ & \\
\hline $\mathbf{B}$ & $112.37 \pm 5.15$ & $340.26 \pm 11.70$ & $686.86 \pm 19.27$ & $1146.76 \pm 55.85$ & $1850.10 \pm 94.41$ & $2584.18 \pm 136.75$ & $1120.09 \pm 211.23^{\mathrm{ab}}$ & \\
\hline $\mathrm{C}$ & $108.39 \pm 0.85$ & $336.02 \pm 3.47$ & $679.42 \pm 9.46$ & $1183.12 \pm 14.48$ & $1947.24 \pm 14.45$ & $2748.43 \pm 15.55$ & $1167.10 \pm 224.93^{b}$ & \\
\hline D & $110.84 \pm 3.70$ & $343.30 \pm 8.38$ & $690.02 \pm 0.94$ & $1147.36 \pm 29.07$ & $1815.76 \pm 72.84$ & $2620.01 \pm 108.83$ & $1121.22 \pm 211.84^{\mathrm{ab}}$ & \\
\hline $\mathbf{E}$ & $110.50 \pm 1.51$ & $341.94 \pm 6.41$ & $688.98 \pm 12.33$ & $1191.25 \pm 48.36$ & $1924.23 \pm 70.25$ & $2653.70 \pm 113.98$ & $1151.76 \pm 218.04^{a b}$ & \\
\hline \multicolumn{8}{|c|}{ Feed Conversion Ratio } & \multirow{6}{*}{ NS } \\
\hline $\mathbf{A}$ & $1.26 \pm 0.03$ & $1.38 \pm 0.02$ & $1.42 \pm 0.01$ & $1.44 \pm 0.00$ & $1.51 \pm 0.01$ & $1.63 \pm 0.01$ & $1.44 \pm 0.03$ & \\
\hline B & $1.23 \pm 0.02$ & $1.33 \pm 0.03$ & $1.37 \pm 0.02$ & $1.41 \pm 0.03$ & $1.51 \pm 0.01$ & $1.63 \pm 0.01$ & $1.41 \pm 0.03$ & \\
\hline $\mathrm{C}$ & $1.29 \pm 0.03$ & $1.33 \pm 0.01$ & $1.36 \pm 0.02$ & $1.40 \pm 0.01$ & $1.48 \pm 0.01$ & $1.61 \pm 0.01$ & $1.41 \pm 0.03$ & \\
\hline D & $1.17 \pm 0.01$ & $1.34 \pm 0.03$ & $1.39 \pm 0.03$ & $1.40 \pm 0.02$ & $1.50 \pm 0.02$ & $1.62 \pm 0.03$ & $1.40 \pm 0.03$ & \\
\hline $\mathbf{E}$ & $1.19 \pm 0.02$ & 1.310 .02 & $1.39 \pm 0.00$ & $1.43 \pm 0.01$ & $1.53 \pm 0.01$ & $1.63 \pm 0.01$ & $1.41 \pm 0.04$ & \\
\hline
\end{tabular}

Means bearing different superscripts differ significantly within a column, $* \mathrm{P}<0.05$

NS - Non-significant, CD - Critical difference.

\section{Economics of Broiler Production}

The prevailing market price of day-old chicks, feed, medication, vaccination, litter material, labor and overheads were considered, while calculating the cost of production (Table 4). It is observed that, net cost of production rupees (Rs.) per kg live weight was 73.62, 73.54, 71.74, 73.27 and 73.79 for the birds from groups A, B, C, D and E, respectively. The net profit per kg live weight was Rs 16.38, 16.46, 18.26, 16.73 and 16.21 for groups A, B, C, D and E, respectively. The birds from group $\mathrm{C}$ receiving diet 10\% L-threonine above NRC recorded highest net profit per kg, followed by the birds from groups D, B, A and E. 
Table 4: Economics of Broiler Production with Supplemented L-threonine at Different Levels

\begin{tabular}{|c|c|c|c|c|c|c|}
\hline \multirow{2}{*}{ Sr. No. } & \multirow{2}{*}{ Particulars } & \multicolumn{5}{|c|}{ Treatment Groups } \\
\hline & & $\mathbf{A}$ & B & $\mathrm{C}$ & D & $\mathbf{E}$ \\
\hline 1 & Chick cost (Rs./chick) & 32 & 32 & 32 & 32 & 32 \\
\hline \multirow[t]{4}{*}{2} & Feed intake (g/bird) & & & & & \\
\hline & 1. Pre-starter & 300 & 300 & 300 & 300 & 300 \\
\hline & 2. Starter & 700 & 700 & 700 & 700 & 700 \\
\hline & 3. Finisher & 1562 & 1584 & 1748 & 1620 & 1653 \\
\hline \multirow[t]{4}{*}{3} & Feed price per kg (Rs.) & & & & & \\
\hline & 1. Pre-starter & 29.32 & 29.55 & 29.70 & 29.84 & 29.99 \\
\hline & 2. Starter & 30.26 & 30.47 & 30.62 & 30.76 & 30.91 \\
\hline & 3. Finisher & 29.73 & 30.01 & 30.14 & 30.28 & 30.41 \\
\hline \multirow[t]{4}{*}{4} & Feed cost per bird (Rs.) & & & & & \\
\hline & 1. Pre-starter & 8.80 & 8.87 & 8.91 & 8.95 & 9.00 \\
\hline & 2. Starter & 21.18 & 21.33 & 21.43 & 21.53 & 21.64 \\
\hline & 3. Finisher & 46.44 & 47.54 & 52.68 & 49.05 & 50.27 \\
\hline 5 & Total feed cost per bird (Rs) & 76.42 & 77.73 & 83.03 & 79.54 & 80.90 \\
\hline 6 & $\begin{array}{l}\text { Miscellaneous cost per bird } \\
\text { (Rs.)* }\end{array}$ & 10 & 10 & 10 & 10 & 10 \\
\hline 7 & $\begin{array}{l}\text { Net cost of production per bird } \\
\text { (Rs.) }\end{array}$ & 118.42 & 119.73 & 125.03 & 121.54 & 122.90 \\
\hline 8 & $\begin{array}{l}\text { Cost of production per kg live } \\
\text { weight (Rs.) }\end{array}$ & 73.62 & 73.54 & 71.74 & 73.27 & 73.79 \\
\hline 9 & $\begin{array}{l}\text { Body weight at the end of } 6^{\text {th }} \\
\text { week }(\mathrm{g}) \text { per bird }\end{array}$ & 1608.53 & 1628.10 & 1742.76 & 1658.82 & 1665.57 \\
\hline 10 & $\begin{array}{l}\text { Return on sale @ Rs.90 per kg } \\
\text { body weight }\end{array}$ & 144.77 & 146.53 & 156.85 & 149.29 & 149.90 \\
\hline 11 & Net profit per bird (Rs.) & 26.35 & 26.80 & 31.82 & 27.76 & 27.00 \\
\hline 12 & $\begin{array}{l}\text { Net profit per kg live weight } \\
\text { (Rs.) }\end{array}$ & 16.38 & 16.46 & 18.26 & 16.73 & 16.21 \\
\hline
\end{tabular}

*Miscellaneous cost includes cost of medicine, vaccine, litter, labour and other overheads

\section{CONCLUSIONS}

Thus, it may be concluded that, the dietary supplementation of L-threonine at 10\% above NRC (1994) was found to be beneficial, in terms of improved growth performance and economic returns in broiler chickens.

\section{ACKNOWLEDGEMENTS}

The authors are highly grateful to Director of Research, MAFSU, Nagpur and Associate Dean, Post Graduate Institute of Veterinary and Animal Sciences, Akola for providing necessary facilities and for his help at various stages of the experiment. The authors are also thankful to M/s. Evonik India Pvt. Ltd. Sakinaka, Andheri East, Mumbai, India for providing the L-threonine for research.

\section{REFERENCES}

1. Ayasan, T. and F. Okan (2011). Threonine requirement of female broilers from 22 to 42 days of age. Ziraat-Fakultesi-DergisiSuleyman-Demirel-Universitesi. 6(1): 15-21.

2. Barkley, G.R. and I.R. Wallis (2001) Threonine requirements of broiler chickens: an experimental validation of a model using growth responses and carcass analysis. British Poultry Science. 42(5): 616-624.

3. BIS (2007). Bureau of Indian Standards, Poultry Feeds Specification. (5thRevision), Manak Bhavan, 9 Bahadur Shah Zafar 
Marg, New Delhi - 110002.

4. Ciftci, I. and N. Ceylan (2004). Effects of dietary threonine and crude protein on growth performance, carcass and meat composition of broiler chickens. British Poultry Science. 45(2): 280-289.

5. Corzo, A., M.T. Kidd, W.A. Dozier III, G.T. Pharr and E.A. Koutsos (2007). Dietary threonine needs for growth and immunity of broilers raised under different litter conditions. J. Appl. Poult. Res. 16: 574-582.

6. Dozier, W.A., E.T. Moran and M.T. Kidd (2000). Threonine requirement of broiler males from 42 to 56 days in a summer environment. Journal of Applied Poultry Research. 9(4): 496-500.

7. Dozier, W.A., E.T. Moran and M.T. Kidd (2001). Male and female broiler responses to low and adequate dietary threonine on nitrogen and energy balance. Poultry Science. 80(7): 926-930.

8. Estalkhzir F.M., S. Khojasteh and M. Jafari (2013). The effect of different levels of threonine on performance and carcass characteristics of broiler chickens. JNAS journal. 382-386.

9. Han Y., H. Suzuki, C.M. Parsonsand and D.H. Baker (1992). Amino acid fortification of a low protein corn-soybean meal diet for maximal weight gain and feed efficiency of chicks. Poultry Science. 71: 1168-1178.

10. Khan, A.R, H. Nawaz and I. Zahoor (2006). Effect of different levels of digestible threonine on growth performance of broiler chicks. Journal of Poultry Science. 16: 1-2.

11. Kidd, M.T. (2000). Nutritional consideration concerning threonine in broilers. World Poultry Science Journal. 56: $139-151$.

12. Kidd, M.T. and B.J. Kerr (1997) Threonine responses in commercial broilers at 30 to 42 days. Journal of Applied Poultry Research. 6: 362 - 367.

13. Kidd, M.T., S.P. Lerner, J.P. Allard, S.K. Rao and J.T. Halley (1999). Threonine needs of finishing broilers: growth, carcass and economic responses. Journal of Applied Poultry Research. 8: 160-169.

14. Li, Y. L. and Y. M. Guo (2000) Threonine and tryptophan requirement of 3-6 week broilers. China J. Anim. Sci. 5:3-5.

15. Maroufyan Elham, Azhar Kasim, Seyed R. Hashemi, Tech C. Loh, Mohd H. Bejo and Homa Davoodi (2010). The effect of methionine and threonine supplementations on immune responses of broiler chickens challenged with infectious bursal disease. American Journal of Applied Sciences. 7(1): 44-50.

16. NRC (1994). http-://www.nrc-cnrc.gc.ca/eng/index html

17. Ojano-Diranin, C.P. and P.W. Waldroup (2002). Evaluation of lysine, methionine and threonine needs of broilers from three to six week of age under moderate temperature stress. International Journal of Poultry Science. 1(1): 16-21.

18. Reginatto, M.F., A.M.L. Ribeiro, A.M.J. Penz, A.M. Kessler and E.L. Krabbe (2000). Threonine supplementation in broiler diets varying in energy and energy : protein ratio. Revista Brasileira de Ciencia Avicola. 2(3): 239- 247.

19. Rezaeipour V., H. Fononi and M. Irani (2012). Effects of dietary L-threonine and Saccharomyces cerevisiae on performance, intestinal morphology and immune response of broiler chickens. S. Afr. J. Anim. Sci. 42(3).

20. Rosa, A.P., G.M. Pesti, H.M. Edwards and R.I. Bakalli (2001). Threonine requirements of different broiler genotypes. Journal of Poultry Science. 80(12): 1710-1717.

21. Sasidhar T., K. Mani, K. Rajendran, T. Vasanthakumar and U. Prabhakaran (2016). Influence of feeding l-threonine on the productive performance of egg type japanese quail breeders in the starter and grower phase. International Journal of Science, Environment and Technology. 5(3): 1079-1082. 
22. Shirzadegan K., I. Nickkhah and M.A. Jafari (2015). Impacts of dietary L-threonine supplementation on performance and intestinal morphology of broiler chickens during summer time. Iranian Journal of Applied Animal Science. 5(2): 431-436.

23. Snedecor, G.W. and W.G. Cochran (1994). Journal of Educational and Behavioral Statistics. 19(3): 304-307.

24. Waldroup, P.W., Q. Jiang and C.A. Fritts (2005). Effects of glycine and threonine supplementation on performance of broiler chicks fed diets low in crude protein. Int. J. Poult. Sci. 4: 250-257. 